\title{
To Segregate or to Separate? Special Education Expansion and Divergence in the United States and Germany
}

\author{
JUSTIN J. W. POWELL
}

Over the past two hundred years in the United States and Germany, special educational systems have been institutionalized to facilitate access to learning opportunities for children with disabilities, difficulties, and disadvantages. Originally heralded as innovative, the positive views of these mainly segregating and separating educational facilities have been increasingly challenged. Despite a multitude of local, national, and international reform initiatives, Germany continues to serve the vast majority of children with special educational needs (SEN) in segregated special schools, whereas in the United States nearly all children with SEN are integrated in general schools, though most spend part of their school day outside the general classroom. This institutional analysis compares the genesis, expansion, and persistence of special education as a multitrack, separating system in the United States and as a dual-track, segregating system in Germany.

The ongoing diffusion of special education has increased access and available services for students with SEN. However, special education's institutionalized organizations also constrain the opportunities that contemporary decision makers, interest groups, and individual gatekeepers and participants have to realize school integration and inclusive education, which have become increasingly - though not universally — accepted goals. Both important similarities and considerable differences in the institutionalization of special education will be emphasized here. Since World War II, there has been not only an extraordinary expansion of educational systems but also convergence in their ideological charters throughout the world (Ramirez and Boli-Bennett 1982; Ramirez and Boli 1987), with compulsory schooling joined by education for all and inclusive education. Nevertheless, "cultural forces for educational convergence are working against the structural forces which condition the endurance of different systems of education" (Archer 1984, 203). This analysis, which explores the growth and inertia of (special) educational systems in the United States and Germany, concentrates on these factors: societal values, educational ideologies, and disability paradigms; interests of professionals, par-

\footnotetext{
This research was funded by the Max Planck Society for the Advancement of Science. For helpful comments on earlier versions of this article, I would like to thank John W. Meyer and John G. Richardson, the editors of $C E R$, especially Mark Ginsburg, and the reviewers.
}

Electronically published March 4, 2009

Comparative Education Review, vol. 53, no. 2.

(C) 2009 by the Comparative and International Education Society. All rights reserved. $0010-4086 / 2009 / 5302-0001 \$ 10.00$ 
ents, and advocates; federal polities and decision-making structures; individual rights and resources; and gatekeepers and authorized selection processes. The cross-national and historical comparison of these factors facilitates an understanding of institutional change and persistence as educational systems have reduced exclusion but struggle to become more inclusive.

Since the beginnings of special education, the merits of various settings to provide support to learners have been debated. Influencing such ongoing local and national discourses, international governmental and nongovernmental organizations-such as the United Nations (Muñoz 2007), the European Union (2008), the Organization for Economic Cooperation and Development (OECD 2004), and the World Bank (Peters 2004)—emphasize education for all as a human rights issue. They accentuate the important contributions that inclusive education can make to enhance learning opportunities, produce skilled workers, and foster social inclusion. Inclusive education does not imply a continuation of "mainstreaming" or "integration" policies of prior decades. Rather, it broadens the focus of educational reform to restructure schooling to embrace learners across the categorical boundaries of disability, social class, gender, ethnicity, national origin, sexual orientation, and religion-and to celebrate that diversity (see Booth and Ainscow 2002).

In international comparison, the United States and Germany have neither the most inclusive nor the most segregated educational systems. Among developed democracies, the range extends from nearly all students receiving additional resources to access the curriculum in segregated settings to nearly all students served in inclusive classrooms (OECD 2004). Although the trend toward more school integration and inclusive education is unmistakable, the development remains far more gradual in Germany than in the United States. The aim here is to understand the origins and development of two national special education systems that were originally quite similar but have diverged over time in response to broad social changes transforming disability, education, and human rights.

\section{A German-American Comparison of Special Education Institutionalization}

In absolute numbers and in proportion, Germany and the United States witnessed dramatic growth in their special education populations over the twentieth century (fig. 1), as special education programs and practices diffused. Around 1900, both countries reported around 12,000 "abnormal" children being served with additional or specialized attention, either in special classes or special schools. In Germany, special education growth was particularly rapid during the late 1950s and early 1960s and again following reunification in 1990, with the SEN population rising to around 6 percent of the student population in general schools, representing nearly half a million children and youth, by 2003. In the United States, growth has been continuously upward. Passage in 1975 of the Education for All Handicapped Chil- 


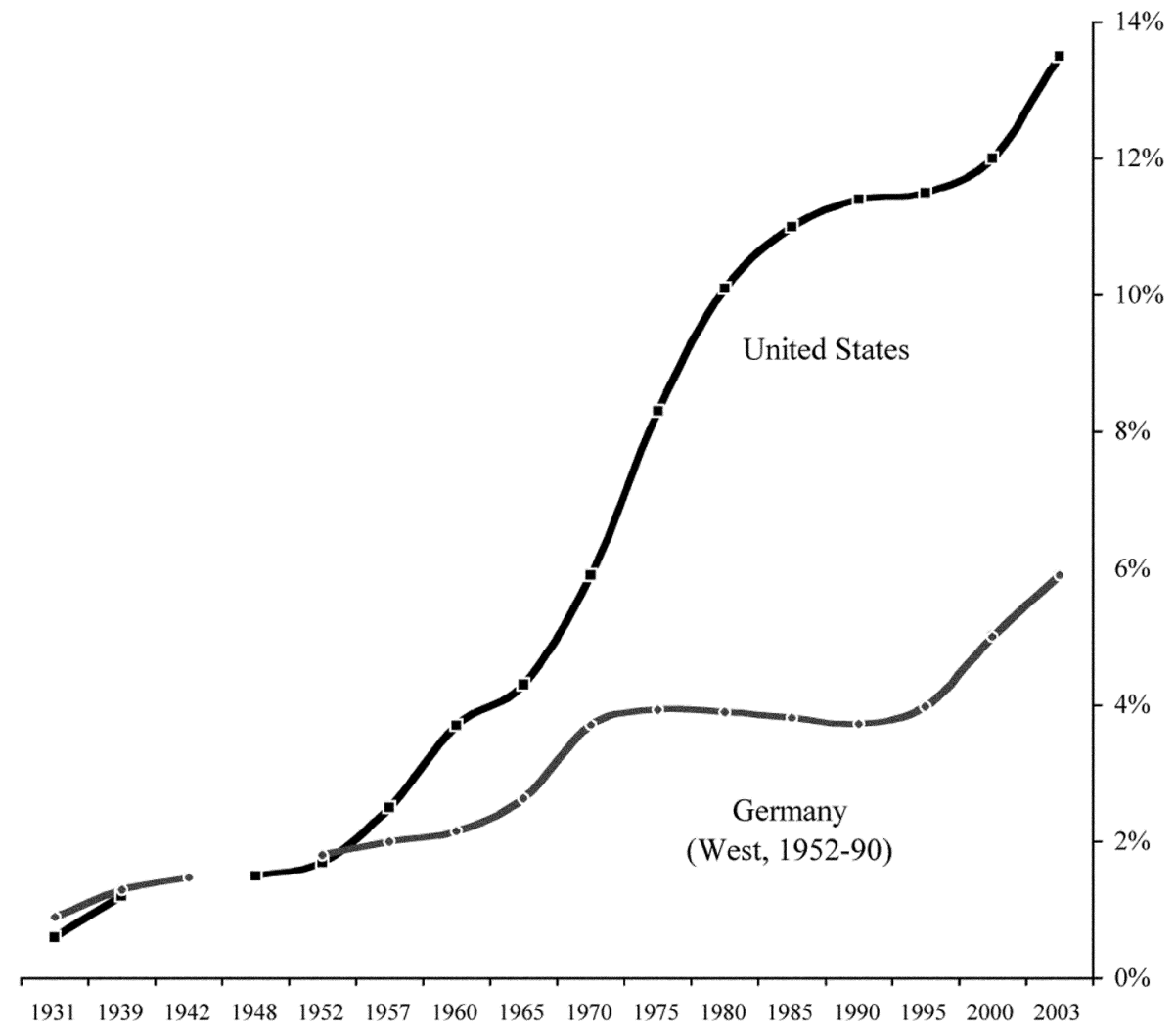

FIG. 1.-Special education classification rates in the United States and Germany, 1931-2003. German official statistics only report students with SEN attending general schools as of the 1999-2000 school year. Sources: Germany-Krappmann et al. (2003), Statistsches Bundesamt Fachserie 11.1 (various years), KMK (2005; KMK 2008). United States-NCES (1996, 2006), U.S. Dept. of Ed. (2007).

dren Act (now titled the Individuals with Disabilities Education Act, IDEA), which guaranteed all disabled children in the United States access to their local public schools as a civil right, led the SEN population to reach 8.3 percent in 1976-77. By 2002-3, more than 5.5 million public school students aged 6-21 received special education services (13.5 percent). These figures signal the increased access to public schooling for children with disabilities as well as elaborated classification systems of SEN.

As special education was institutionalized, its programs developed to serve a heterogeneous group with physical and intellectual difficulties or disabilities as well as social, ethnic, and linguistic disadvantages. Responding to the challenge of increased heterogeneity, classifications and their categories were differentiated, as were school systems themselves, informed by growing disciplinary knowledge and power. Categories applied since the early 1990s underscore the considerable national differences in SEN. The U.S. categories refer to individual student disabilities, whereas the German categories represent ed- 
ucational supports that are still mostly provided in segregated settings. ${ }^{1} \mathrm{Al}-$ though special education organizations in both societies have served a population of students continuously changing in size and composition, these have disproportionately served children with lower socioeconomic status (SES), those belonging to ethnic or racial and migrant or linguistic minority groups, as well as increasingly integrated children with disabilities (Powell 2006). Ambivalent and often contentious, the classification of children as having SEN requires extensive mediation between its many positive and negative consequences: provision of rights and additional resources but also prevalent stigmatization, even institutionalized discrimination, frequently lasting throughout the life course (Powell 2003a, 2003b).

Turning from classification to allocation among available learning opportunity structures, the contrast between national educational systems becomes even clearer. Despite a growing diversity of organizational forms in some German states (Länder), there is as yet no significant "continuum" or "cascade," as in the United States, but rather the institutionally constituted either-or of special or general school (see fig. 2). In the United States in 2005 , over half of all special education students spent almost the whole school day in general classrooms, a quarter spent a majority of the day in regular education (integration), a further 17 percent were schooled mainly in special classrooms (separation), and only 4 percent attended separate facilities (segregation). In Germany, 83 percent of all students with SEN were segregated in 2005. However, most students with SEN attending general schools spent most if not all of their school day in the general classroom, since few general schools have special education teachers and classrooms. Unlike the more flexible and often temporary supports offered within American schools, children once diagnosed as having SEN in Germany attend special schools, rarely returning to general education (Preuss-Lausitz 2001). Four decades of integration attempts have failed to transform the rigid, segregated system of school types with continuous selection-all with the goal of building supposedly homogeneous student groups. The American model's comprehensive schools are outwardly democratic and egalitarian, but many schools continue to stratify within via tracking, which also aims to produce more homogeneous classes (Lucas 1999). Nevertheless, U.S. schools allow more flexibility in curricular planning and permeability in allocation to courses or tracks, while German schools do not (Hamilton and Hurrelmann 1994). Germany's stratified and selective Länder educational systems differentiate

\footnotetext{
${ }^{1}$ Current U.S. categories of individual impairments, disabilities, and special needs are autism, deaf/ blindness, developmental delay, gifted and talented, hearing impairments, mental retardation, multiple disabilities, orthopedic impairments, other health impairments, serious emotional disturbance, specific learning disabilities, speech or language impairments, traumatic brain injury, visual impairments (U.S. Dept. of Ed. 2005). German categories of support are bodily and motor development (Körperliche und motorische Entwicklung), chronic illness (Kranke), emotional and social development (Emotionale und soziale Entwicklung), hearing (Hören), learning (Lernen), mental development (Geistige Entwicklung), multiple/ unclassified (Mehrfach/nicht klassifiziert), seeing (Sehen), and speech (Sprache) (KMK 2008).
} 


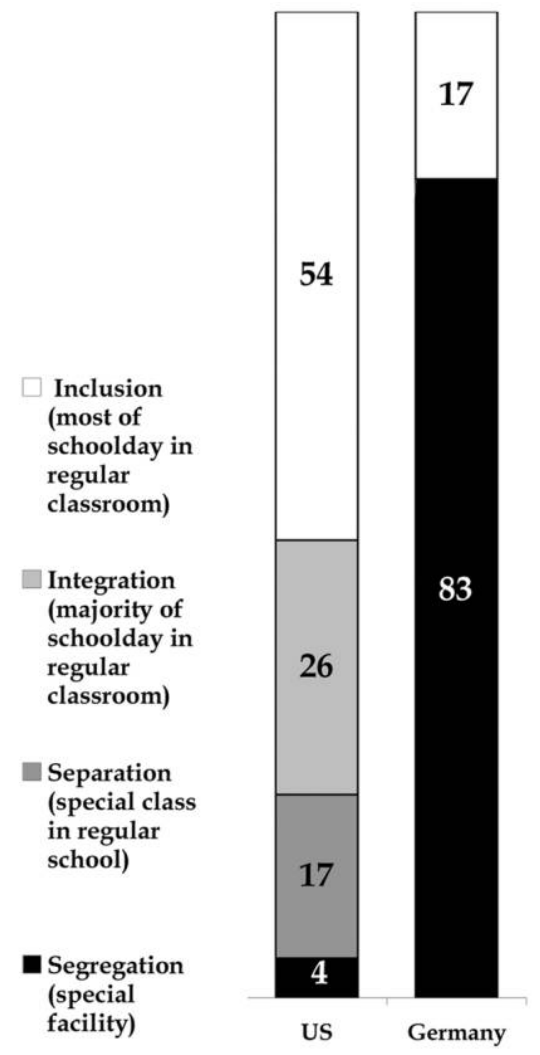

FIG. 2.-Special education learning opportunity structures in the United States and Germany, 2005; author's calculations. Sources: KMK (2008), U.S. Dept. of Ed. (2007).

children of all dis/ability categories after only 4 to 6 years of primary schooling into separate secondary and special schools, with these organizational forms differing considerably (Below 2002). During extended schooling careers, organized learning processes in schools are crucial to support learning, even as students exhibit various abilities, resources, and identities as well as particular ways of dealing with the requirements and challenges of attaining culturally valued knowledge and skills.

Looking to the consequences of these differently structured educational systems on individual outcomes, four-fifths of those youth leaving Germany's segregated special schools do not attain the lowest qualified certificate (Hauptschulabschluss), without which vocational training opportunities and hence labor market chances are seriously limited. By contrast, nearly half of American special education students graduate from high school with a regular diploma, the credential necessary (but not sufficient) for entry to postsecondary education and most entry-level jobs. With educational expansion, the German Hauptschulabschluss and the American high school certificate (where offered) 
have declined in value. In fact, educational expansion has led to the increasing exclusion of less educated youth, whose group size has declined, from vocational training and from many occupations (Solga 2002). Despite the access they have won to educational systems, school leavers from special education programs suffer a vicious cycle of cumulative disadvantage, as they represent a growing proportion of America's "working poor" and, to a greater extent, Germany's long-term unemployed and social assistance receivers (see Daly 1997).

Why did these originally similar systems diverge over time? Institutional theory offers a useful approach to answer such a question. In modern societies, institutionalized rules act as powerful myths built into society as ways of interpreting the world that influence both the original formal structure of organizations and their ability to survive and retain their legitimacy (Meyer and Rowan [1977] 1992). If institutions are social patterns that have achieved a certain state or property (Jepperson 1991), then institutionalization represents the foregoing process, during which organizational structures evolve. Further, the concept of "institutional logic" reaches beyond the symbolic to specific organizational structures that are politically defended, constrained technically and materially, and thus historically specific (see Friedland and Alford 1991). Thus, there is not just one institution or "institutionalization" of special education, there are many, as the resulting nation- and region-specific continua of organizational forms and the diversity of corporate and individual actors involved attests. As David Baker and Gerald LeTendre (2005, xii) have shown, "schooling is shaped and changed by a world culture of values about education . . . producing remarkable similarities. . . . Yet there are striking differences from nation to nation, and from place to place within nations." Here, I examine the case of special education by comparing two countries with different institutional logics in schooling and different institutionalization trajectories of separating (American) and segregating (German) educational systems.

This study focuses on three key institutional processes (isomorphism, expansion, and inertia) to investigate how special education organizations were institutionally embedded in national educational systems and why the German and American special education systems have increasingly diverged. If in these federal systems the regional variance reflects the origins and developmental paths of specific state/Länder educational systems (Hofsäss 1993; Richardson 1999), this cross-national comparison emphasizes the institutional division of special and general education.

\section{Embedding Subsidiary Special Education}

Reflecting societal values and dis/ability paradigms, special educational systems have imitated general educational systems in each country. Even as both systems reduced the exclusion of children with disabilities, especially since the 1960s, they did so without departing from the path established on 
the eve of the twentieth century: the independent, segregated Hilfsschule in Germany and the separate class within the comprehensive school in the United States. Special education, dependent on transfers and serving those barred from or selected out of general education, assumed the institutional logic of each expanding, differentiated national educational system, becoming a subsidiary program.

Special education expansion derives from two sources, one largely exogenous, the other significantly endogenous. The first wave of growth followed universalized compulsory schooling mandated by laws in Germany and the United States that greatly increased the heterogeneity of student bodies in existing public schools. Schools and teachers responded to the challenge that diverse students pose for schooling efficiency by establishing new organizational forms, justified by the nascent academic and professional field of special education and related fields. Educational expansion facilitated affirmation of the goal of schooling for all children, yet growing diversity led to official differentiation and standardization as attempts to resolve the tension between expanded access and organizational constraints. As John Richardson (1999) has shown, rules of access and of passage governed the exemption of those deemed "ineducable" or "disabled." The second expansion wave was self-generating and self-reinforcing as special educators responded to the supply of students provided by general educators by elaborating the categories to identify these students and increasing the organizational options to school them. In the German case, this wave led to more than a dozen special school types. In contrast, American special educators defined individual "exceptionalities" (later "disabilities" and "SEN"), eventually including 14 categories of students attending special classes, from "developmentally delayed" to "gifted and talented." Furthermore, the contemporary developments of Germany's stable, segregated special school system and the everlarger special education programs of the United States, mostly located within comprehensive schools, exhibit considerable path dependence. American states, much more so than Germany's Länder, have increased the permeability between these two branches of education.

\section{Isomorphic Educational Structures}

To explain isomorphic institutional change-structures becoming more similar over time-it is useful to distinguish three types of homogenizing pressures: coercive, from political influence and legitimacy needs; mimetic, as a response to uncertainty; and normative, through professionalization (see DiMaggio and Powell 1983, 1991; Scott 1995). All three types help to distinguish the complex, dynamic subsidiary relationship between general and special education. As rationalized states gain dominance over (public) schooling, schools increasingly reflect rules, laws, and organizational forms legitimated and institutionalized by the state (Meyer 1992). Directly imposed or 
not, standardization, compatibility, and coordination demands apply pressure on organizations that are dependent on the state for resources, authority, and legitimacy. Despite such coercive pressure, special education professional associations successfully mediated the myriad demands of governments, schools, members, and advocates to advance the interests of the profession.

Early on, Prussian civil servants created an administrative division within the central state bureaucracy for "support schools," or Hilfsschulen. American local school boards instead set up special classes in city school districts. In both contexts, the resulting educational administrations emphasize formal, ritual compliance, to which these special schools and classrooms are testaments because their efficacy - and far more their equity-have been continuously questioned and debated since the very beginnings of special education. Especially since the human rights revolution after World War II, which accentuated personhood, governments have been keen to ensure that local school systems include children with disabilities, mandating the provision of services for them.

Mimetic processes can be found in the modeling of new (special) education organizations on the successful ones already operating in the field, given such limited alternatives to special schools and classes as asylums and state institutions. The latter lost their legitimacy as disability was demystified and ordered by special education, mainly in conjunction with the clinical professions of medicine and psychology.

The process of professionalization represents the third isomorphic pressure-normative. Professionals guard their occupational autonomy, attempting to control how and where they work. The establishment of specialized training programs, research to legitimate particular treatments or teaching methods, and professional associations to network the people and disseminate the results are another primary source of isomorphic change. For these reasons, the organizational forms established in special education programsexpanding beyond, but remaining dependent on, general education for most of its students-were institutionally isomorphic to those of general educational systems.

The institutionalization paths of special education differ between Germany and the United States. In Germany, the segregated school type that provided support for "abnormal," mainly poor, children served as the model for later differentiation. In the United States, these children may have remained in general schools but in lower curricular tracks, with special education offering a further option (often in conjunction with grade retention) below the academic, general, and vocational levels. In both cases, special educators sought to care for and control children with disabilities, substituting for asylums, families, and general education. The German competition between school types in a hierarchical educational system (interschool) contrasts with the competition within American individual comprehensive schools (in- 
traschool) and between districts due to residential patterns that produce considerable resource inequalities.

Special Education Expansion

In both Germany and the United States, "functional" differentiationresponding to increasingly heterogeneous student bodies originally resulting from compulsory schooling and child labor laws-was later reinforced by changing pedagogical assumptions about learners as individuals with complex, special needs (Garnier 1980, 91). Special education's dependence on transfers from general education (representing demand) was complemented by its elaboration of classification systems (categories), lobbying activities, and offers of support (representing supply). The first waves of expansion were driven by policy makers' decisions such as passage of compulsory schooling laws, industrialization, demographic changes (immigration, urbanization, increased longevity), and nascent disciplines (e.g., statistics, psychometrics). The second expansion phase resulted from (special) educators strengthening their profession through the specializations that they elaborated.

While these developments affected population size and composition, massive special education expansion (from the mid-1950s) was driven by the conflation of two distinct student groups associated with pedagogies and professional divisions: those with low-incidence, "hard," or "nonnormative" disabilities (such as blindness) and those with high-incidence, "soft," or "normative" disabilities relating to learning or behavior standards.

In Germany, the national supply of special schools (Sonderschulen) peaked in 1999, a quarter century after the Education Council declared inclusion to be preferable to segregation. While some Länder have begun to consolidate or transform Sonderschulen into resource centers, others continue to build them anew (touted as infrastructure investments), producing yet more supply. Effectively, educational systems are stratified in five "dis/ability" tiers. Yet some Länder serve a large minority of students in inclusive education, at resource centers, or with ambulatory services, demonstrating that even in Germany special schools are not the only method to provide individualized support. Model programs, which have proven effective, have encouraged some Länder to pass laws extending or even prioritizing inclusive education, even if adverse fiscal conditions and political priorities hinder their expansion.

In the United States, inclusion may be a goal to which many school gatekeepers, school systems, and state educational agencies subscribe, but since the original IDEA law was passed in 1975, innumerable court cases have been necessary to provide access for children with disabilities to their local public school. Even as half of all American students in special education remain in the general classroom for most of their school day, considerable differences between states remain. Nationally, still a quarter of all special education students are separated for most of their school day or segregated 
the entire day. In some local districts in the United States, expansive definitions of SEN or risk, along with extensive "child find" activities have led to such low "classification thresholds" for special education that up to a third of all students spend some portion of their school day in special education classrooms. The expansion, especially since the mid-1960s and with a recent surge since the No Child Left Behind Act (NCLB) of 2001, resulted in special educational services being offered within nearly every school. At the same time, districts must also maintain or fund a continuum of placement options, often ranging from residential segregated facilities to full-time inclusion in general classrooms, providing the least restrictive environment (LRE) for particular students at a wide range of costs.

As national and Länder/state educational systems expanded, special education experienced both exogenous and endogenous growth as it became embedded within local schools and systems. Simultaneously, both German and American educational systems have witnessed struggles to reduce the outright exclusion, segregation, or separation of children and youth with disabilities. Increasingly over the twentieth century, children considered to be disabled have participated in public schooling, but only since the $1970 \mathrm{~s}$ (and not 1870, as many claim; see Meyer et al. 1992) has truly universalized primary and secondary schooling been achieved. The contemporary challenge for proponents of inclusion is to restructure institutions once again to educate all children together full-time. This goal, however, contradicts the logic not only of Germany's vertically differentiated, segregating system but also of the American comprehensive, separating system. Although some localities and states have realized such fundamental change, opportunities for such path departure are constrained by the legitimacy of the respective segregating and separating structures of special education, by the specialized, additional resources that special education provides, and by the authority of and vested interests in special education.

\section{Persistent Separation, Resistance to Inclusion?}

School systems and individual schools are deeply embedded in the ideologies and institutional arrangements of the Länder/state educational systems. Specific historical structures in these educational systems exhibit considerable institutional inertia. Such factors as the enactment dates of compulsory schooling laws, as an indicator of the "institutional age" of a state educational system (Richardson 1999), shaped the development of special education programs. Early establishment of particular asylums or special education facilities pioneered not only disciplinary ontologies and methodologies but also organizational strategies and structures.

Yet innovative programs that challenged the status quo have been repeatedly realized, usually with extraordinary effort. There are national and regional differences not only in institutional embeddedness but also in vested 
interests and in the extent of centralization (see Archer 1984). The influence of these origins and historical paths on later development and persistence is heightened in the German and American decentralized systems because subnational policies provide the frameworks and the conditions within which local school systems operate. Further, the loosely coupled structure of schools restrict the impact that top-down reforms have on state and local education administrations and local schools: "Decoupling enables organizations to maintain standardized, legitimating, formal structures while their activities vary in response to practical considerations" (Meyer and Rowan [1977] 1992, 57-58). In both countries, the reality in schools neither wholly reflects the law nor the restructuring that social movements and educational researchers have underscored as key to realize inclusive education. This gap between the conditions necessary for inclusive education and standard operating procedures has raised doubts about its countrywide implementation (Kavale and Forness 2002), yet a wide range of schools has examined taken-for-granted assumptions, moved beyond bureaucratic compliance, and become fundamentally transformed into inclusive schools (Ware 2004; Villa and Thousand 2005). Special and inclusive education debates persist, although a settlement may be found in melding the systemic focus on necessary conditions for educational restructuring with attention to reformed local practices that serve each child's individual needs (Andrews et al. 2000).

Growth in existing organizations proceeds in educational systems along paths chosen long ago and influenced by the dynamics of which student bodies attend which schools and which teachers instruct them. Specialization and accessibility costs are traditional functional arguments brought routinely to justify separate organizational structures and to counter proposals for the shift to integration and inclusive education. However, educational access, elimination of physical and communication barriers, and technological advances as well as antidiscrimination laws that emphasize individual rights reduce the legitimacy of separation and segregation.

In Germany, integration has been exceedingly difficult to achieve against the legitimated selective system and its vested interests, exemplified in the modest success of comprehensive school reform: Gesamtschulen were an addition to, not a replacement for, the traditional sponsored mobility system (Leschinsky and Mayer 1999; see Turner 1960). Higher- status groups mainly hindered this reform through the mechanism of party politics, but they also supported model inclusive education programs in some Länder. Although this lost battle reduced the overall potential for integration, the comprehensive schools also often refrained from including students with disabilities in their integrative vision.

In the United States, internal differentiation is by track, with interests and ability paramount in the decision to take college preparatory, general, or vocational courses. Although the opponents of tracking have been vocal, 
it continues to occur more or less informally, and even the American comprehensive system has yet to implement fully inclusive educational programs for half of the student population classified as having SEN. In these contrasting institutional arrangements, segregation and separation are difficult to overcome due to institutional inertia and to each system's legitimated processes of differentiation and allocation (see Carrier 1986). These contrasting special education programs within expanding national educational systems, institutionalized in path-dependent fashion, reflect societal values, educational ideologies, and dis/ability paradigms.

Values, Ideologies, and Paradigms

Societal values and educational ideologies, but also societal and schoolspecific conceptions of dis/ability, frame German and American (special) educational systems. These values legitimate the symbolic and social boundaries drawn around categories of students that receive different opportunities and resources to access the school curriculum. At the nexus of individual dis/abilities, schooling, and social reproduction, special education remains a contentious, ambivalent institution because it simultaneously offers additional or specialized resources and (usually) confers stigma and an official status of abnormality (Powell 2003a). As nation-states, policies, and science have developed, ab/normality and dis/ability have been continuously elaborated in statistical classification systems. These systems reflect shifts in educational values, goals, and interests but also mirror the state and society in which they guide the process of sorting students. Thus, to understand the institutionalization of special education requires attention to the ideals and values manifest in the boundaries drawn around those who have been considered "ineducable," "abnormal," "exceptional," "disabled," or "special."

Germany's conservative welfare-state regime places primacy on the family, social insurance and redistribution, and integration through state provision. Education and social policies remain separate, even in special education, where provisions of personal assistance and technical aids may be keys to accessing curricula. Citizens are integrated into the German nation from above, as the state frames society with rules, public laws, and administrations addressing each stage of the life course (Mayer and Müller 1986). While both countries have highly bureaucratized and state-regulated school systems, Germany not only has provided less schooling than the United States but such schooling also has been more highly stratified, as compared to American "exceptionalism," with regard to class formation and political processes (Rubinson 1986).

If German schooling serves to enhance individual life chances, it also maintains status differences and produces order by building homogeneous groups. School placement rests on measured past academic achievement, which determines appropriate support for each individual to develop his or 
her "natural aptitude" or "given talent" (Begabung)—with this ideology being a German idiosyncrasy that affects all levels of education (Lenhardt 2005, 27ff.). The corporate institutional logic of selection leads to students being sorted into groups defined by secondary school types; however, individuals with exceptional talents are not separated out to receive individualized, additional support. By contrast, in many U.S. states, special classes for "exceptional," "gifted," or "talented" children have long constituted a part of public education. In Germany, students are defined less by their unique individual personality than by the school type that they attend, which is determined by grades, teacher evaluations, and school recommendations. Distinctions between school types remain strict, despite increases in comprehensive school attendance and the rising stigmatization and the decreasing vocational training opportunities associated with attending low-status types of schools.

Whereas Germany imported a liberal democratic order after World War II that is now thoroughly supported, the individualistic and meritocratic values of the "American ethos" have resisted change over 200 years (Fuchs 2000, 67ff.). As a liberal-individualist state, the United States offers scarcely more than basic income programs. In the value system of competitive individualism, success or failure is attributed to individual performance. The American obsession with individual opportunities and competition, educational and otherwise, leads to one of the best-funded school systems in the world. After providing primary and secondary schooling, however, the state's duties toward citizens are circumscribed. Unlike Germany, the United States invests more in education than in redistributive antipoverty or basic income schemes (Heidenheimer 1984). Free public education and the increasing number of categorical programs, like special and compensatory education since the 1960s, are taken to be among the most important social provisions that the U.S. federal government can mandate. Since the beginning of "common schooling" and enactment of compulsory schooling laws between 1850 and 1920, American public schools have been among the most inclusive in the Western world, responsible for integrating children from different classes, religions, and national origins (Tyack and Cuban 1995). Politicians based their decisions on moral-religious values that reflected an integration ideology emphasizing individual and political freedom, equal opportunity, achievement, and civic engagement through personal equality and independence, as the "good society" derives from society itself, not through state action (Bellah et al. 1985). The crucial exception was the inegalitarian system of racial segregation in the American South, which led to societal conflict, struggle, and eventually federal government force to ensure school integration on the basis of race, a significant precursor for integrating students with disabilities.

Maintaining democratic values and enhancing individual life chances are the most important goals of American public schooling, affirmed in such 
landmark Court decisions as Brown v. Board of Education in 1954. These goals are to be realized by (1) integration through participation in comprehensive schools that reflect the pluralism of the places in which they serve as community centers and (2) individual aptitude and achievement, continuously measured by standardized tests. Especially important in an immigrant nation, public comprehensive schools were to create a unified American society out of myriad cultural, linguistic, and religious groups (e pluribus unum). Even if equal opportunities are not always forthcoming or realized in practice, especially due to residential segregation and disparities on the basis of wealth and ascriptive characteristics such as gender and ethnicity, they are idealized.

Meritocratic myths are among the most powerful of American beliefs. Large investments in education focus on leveling the playing field, to a certain extent, for all individuals. Yet unequal educational outputs and outcomes are not only tolerated but celebrated: individual students are ranked by and publicly rewarded for their outstanding academic, aesthetic, or athletic achievements. Orientation toward the future emphasizes not only aptitude but also effort, and most especially personality development. This view encourages belief in each person's unique potential, growth, and contributions. Within this logic, individual "exceptionalities" are to be acknowledged, compensated, or further developed to ensure the best possible performance. Thus, the federally mandated individualized educational program (IEP) that every student in special education receives can be understood as a thoroughly American individualist solution, related to the contest mobility system of education in contrast to Germany's sponsored mobility system (Turner 1960).

Both societies share meritocratic values typical of Western capitalism, with individual achievement and performance most important but with social justice-providing for needs, compensating for disadvantages-also crucial (Roller 2000). The balance of these values is dynamic and relative, however, as often-conflicting historical and contemporary education ideals such as integration or segregation are reflected throughout these educational systems. On the whole, American schooling has aimed for common schooling to provide equal educational opportunities that facilitate meritocratic competition but with accepted large disparities of outcomes. German schooling, an aspect of the state's benevolent paternalism, historically aimed for appropriate status (and its maintenance) in schooling, elaborate vocational training, and occupational careers. Moreover, this status-based-as opposed to ranking-based-logic extends to individual schools and students. That some students will always deviate from the norm emphasizes the importance of culturally specific definitions of "special educational needs."

Although people with disabilities are frequently stigmatized in both societies, educational responses have varied considerably within the countries and over time, suggesting that additional factors are necessary to explain the divergent institutionalization of special education as well as tenacious regional 
variance. If the dominant German classification system over the postwar period reified disabilities in many generously staffed but segregated special school types, the American system maintained medical-model disability categories to specify legitimate functional needs to compensate, even as society moved beyond the clinical deficit paradigm to include economic and more positive sociopolitical, minority, and human variation models of dis/ability. Indeed, inclusive education reforms must explicitly engage broader societal attitudes toward disability, especially as these shift from a clinical model to one that understands disability as an ascriptive category similar to race, gender, and class (Ware 2004, 185).

In which direction these systems will move depends not only on institutionalized ideologies and values but also on interest groups' current political influence and protest activities. Whereas disability activists and advocates in the United States facilitated enactment and implementation of progressive policies, in Germany the special education profession was most effective at lobbying for further differentiation and expansion of special school systems. Whether path dependence or departure is most probable depends on the organizational structures, on the interests that succeed in producing or shifting local or regional ideological consensus, in dominating the decisionmaking process, and ultimately on shifting gatekeepers' range of options.

\section{Professionals, Parents, and Advocates}

Certain interests in maintaining or changing special and inclusive education have been more successful in setting the political agenda and reforming special education organizations than others. The diverse interests of advocates for students with disabilities, professionals, parents, and policy makers have often led to conflicts with clear winners and losers. Who mobilized to change schools to reduce the exclusion of children and youth with disabilities? How much did they influence policy makers in controlling the agenda and affect gatekeepers working within schools? An understanding of interest groups and their victories and defeats is necessary to explain the (divergent) institutionalization of special education.

Political parties have played a less significant role in disability policy than in educational matters generally or in representing certain perspectives on fiscal priorities or values and ideologies such as equality and social justice. More important, professional interests of special educators, physicians, and psychologists have influenced the expansion and persistence of special education's organizational structures. The classification systems constructed and legitimated by these professional fields influence research agendas, teacher training, and knowledge and awareness more generally. Powerful membership associations have continuously lobbied national, state, and local policy makers and the various branches of government.

While coalitions of parents and disability advocacy organizations have 
effectively used pressure and protest to limit the power or shift the goals of professional associations, they have done so most often according to the logic of the education system-in Germany, favoring segregation, and in the United States, favoring separation. Nevertheless, the American disability rights movement and the German system, which followed the U.S. model with some delay, successfully utilized a rights-based strategy with lobbying, protests, and court cases being crucial factors to achieve passage of educational access and antidiscrimination legislation. If the U.S. judiciary has treated children with disabilities as a group in need of protection, in Germany the interests of children with disabilities have consistently been weighed against those of the majority, in effect implementing cost-benefit analysis to the aim of inclusion (Degener 2001, 45). German public opinion, dominated by large neocorporatist organizations, is far more rigid than the American, in which innumerable flexible interest groups arise continuously to champion new issues and causes (Savelsberg 1994).

In Germany, the most influential group was and is the special school teachers and administrators, organized in a highly successful membership association. Since 1898, the Verband deutscher Sonderpädagogik (VDS) and its precursors have provided a strong voice and professional legitimation for the special school system. In the postwar period, the VDS 1954 white paper that was distributed to Länder cultural ministers caused a critical juncture, as it led to the profession-inspired, not empirically validated, differentiation of separate school types. Since then, special educators have established, controlled, and defended a dozen discrete school types based on disability categories. By contrast, a multitude of American advocacy organizations, the disability rights movement, and parent-activists gained access to schooling and ensured that special education would be offered in comprehensive schools, thus reducing segregation. At the national level, the Council for Exceptional Children (1922-) coordinated the lobbying effort needed for Congress to eventually pass the IDEA legislation guaranteeing all disabled children a "free, appropriate public education" in the "least restrictive environment” (1975). Special educators in a comprehensive school system did not so much argue for their own school type, although special schools existed, but, rather, for mainstreaming, which would potentially provide access to every comprehensive school. Special educators recognized their interests in this new policy, and an unusual coalition of political actors created the necessary consensus to pass it (see Melnick 1995). To guarantee that this categorical program would not be abused but also that public schools would no longer shirk their duty to this vulnerable class of students, an extensive, heavily bureaucratic program developed within each district, including "child find" recruitment requirements codified in law (Baker 2002).

The specific resources and rights demanded by the disability movements, parental groups, and advocacy organizations in Germany and the United 
States vary along with the differences in group strength. The professional fields of special education, medicine (rehabilitation), and psychology, together with administrators at all levels, advanced their interests in both institutional expansion and continuity. Professional associations have played particularly salient lobbying roles in national and state, but also local, contexts. The resulting social, political, and economic conflicts between levels of government and between special and general education led to increased legal oversight and bureaucratization of public schools.

Disability organizations and the disability movement increasingly influence politics and reform in both countries. Here again, however, there are important differences that reflect particular historical experiences, legal traditions, and welfare state programs. The American disability movement followed the civil rights movement in demanding rights, with legislation and litigation resulting from often vague policy guidelines (e.g., the words "integration" and "inclusion" are nowhere to be found in special education law) that require judicial review and interpretation. Unified in arguing for enhanced services, parents and advocates have found no consensus as to the most appropriate educational environments. The debate about organizational placement has been a constant on both sides of the Atlantic.

\section{Coercion, Cooperation, or Consensus?}

Despite both countries' being federal democratic polities, the German and American decentralized decision-making structures determine differently the opportunities available for interest groups to affect existing policies, particularly in education (see Münch 2000). The degrees of centralization, relevant educational regulations, and types of federal legislative and judicial action have especially structured the opportunities for change. While in Germany each Land retains control over education, in the United States local districts and schools exercise far more autonomy vis-à-vis both state and national governments. In both contexts, national decision-making bodies have had considerable impact on schooling, albeit in different directions. German consensus building among the Länder hinders national path departure and favors incremental change, whereas the U.S. federal government mandated individual civil rights relating to schooling, securing those rights coercively when necessary. In each country, laws, regulations, and funding formulas are differently distributed among governmental levels, producing particular incentive structures.

Germany's intrastate, interlocking federalism divides powers exclusively by policy field with clear constitutional mandates. While the federal parliament is responsible for civil rights legislation, Länder must also codify and implement these laws. Successful efforts to reduce regional disparities through considerable redistribution also maintain economic and cultural homogeneity. Since education belongs to a Land's cultural sovereignty (Kul- 
turhoheit), developments in special education are not a federal prerogative, whereas social policy programs such as transfer payments to individuals with disabilities are. Due to the experiences during the National Socialist regime (1933-45), education has been purposefully, carefully protected against national government control.

By contrast, U.S. interstate federalism emphasizes the vertical division of power and competition between the executive, legislative, and judicial branches. The American division of competencies with clear constitutional mandates is by function (federal law making, state administration), not by policy field. States delegate educational responsibility to local districts. With a desire for a strong society, not state, centralization tendencies are rejectedexcept to guarantee civil rights, integration, and equality of opportunity. These key aspects affect (special) education and have led to increasing centralization at the levels of discourse and policy making but not particularly in the financing and control of school districts and schools. Increasingly ambitious and highly prescriptive special education policies have passed without generating much controversy or opposition, largely due to the judicial action and the framing in terms of individual rights that united a diverse reform coalition (Melnick 1995). The federal government has greater power to support inclusive education and reduce school segregation.

Civil rights relating to public education and integration have been protected by innumerable affirmative federal court decisions, resulting in extensive judicial regulation of American education, of which special education is a paradigmatic case. Congress created a right for disabled children through a special categorical program with the bureaucratic mechanism of the IEP and imposed this right by court decree when lower-level bureaucrats were unwilling to provide "free, appropriate public education" of their own accord (Neal and Kirp 1986). Parents have effectively litigated against school districts that did not provide appropriate services or educate their child in the "least restrictive environment," even prior to congressional action. In stark contrast to the first half of the twentieth century, children with SEN have been considered a "suspect class" - a group deserving of such high protection that any discriminating state action must survive the court's strict scrutiny-which the federal and state courts have repeatedly protected. Litigation to ensure access to and participation in public school systems has confirmed both school integration and inclusion in general classrooms, where appropriate, to be inalienable rights for American students.

In Germany, by contrast, parents must bear the costs of litigation, first seeking decisions from administrative, and then constitutional, courts. In those few school integration cases that the Federal Constitutional Court has heard, it has hesitated to force Länder to change their school laws to be more inclusive, arguing that while preferable and an individual right, inclusive education is contingent on Länder policy making and finances. The court 
has taken into account the "interests" of the other students, fiscal concerns, and political decision-making structures. Gradually, decisions carry over into federal parliament deliberations and Land policy making. Despite European Union (2008) policies supporting inclusive education, Germany's Culture Ministers' Conference, which coordinates Länder consensus-based policy making, offers only recommendations. The wide range of legal statements and organizational solutions was bolstered by Federalism Reform (2006) that further increased Länder autonomy regarding education.

\section{Rights and Resources}

Groups that mobilized to win rights and resources in both the United States and Germany were often satisfied with legislative and judicial advance without following through on state and local implementation and enforcement. American and German advocates share the necessity to ensure that the formalities of legislative policy making, commissioned accountability reports, and legal decisions are carried out locally. Decentralized decision making supports the regionally specific status quo.

Multiple levels of government provide fiscal support for special education, producing incentive structures that encourage teachers and other gatekeepers to classify or segregate students. Funding systems may reward or discourage classification, the provision of certain services, particular placements, or all three. The German separation of special and general school systems has a corresponding barrier in the separation of social and educational policy. Thus, the actual costs-not only in terms of reduced life chances and social exclusion-often remain hidden from policy makers' decision-making processes. Yet vested interests and lobbies resist the calculation of segregation's actual costs; very few studies comparatively document the costs of various educational environments (Preuss-Lausitz 2002).

In the United States, costs have not been the main consideration in judicial decision making. Nevertheless, the continuously rising special education population reached a fiscal limit during the 1990s, with many states responding to the fiscal drain by reforming their special education finance laws to reduce incentives to classify and separate or segregate students (Parrish 2001). Limits on the proportion of students who may receive special educational services or on how many students may participate in inclusive education programs have long led many interest groups to call for federal, state, and local policy reform. Since the NCLB Act of 2001, the debate over unfunded mandates and costs has risen as funds to realize federally mandated high standards are lacking.

Special education finance may inhibit integration and inclusion, especially if finance and service provision are linked with particular settings and not with the students themselves (Meijer et al. 1994). German special education financing rewards segregation, especially given infrastructure invest- 
ments in small-scale special schools, whereas the U.S. system rewards classification. While provision of special education services is determined largely independently from settings, mostly within the comprehensive school building, the "least restrictive environment" for an individual student may well be another (more or less costly) setting. Increasingly in the United States, rights have come before resources, with decisions about individual cases decided favoring students with SEN. As American spending on general and special education is high, and rising, numerous precedent-setting cases and congressionally commissioned educational research have encouraged legislators to generalize innovations in required congressional reauthorizations of special education policies. Meanwhile, both countries face an increased emphasis on standards-on schools' outputs measured by students' performance, achievement, or attainment.

\section{Opening the School Gate-or the Classroom Door}

Beyond the elimination of outright exclusion, German and American reforms to shift the allocation of students among learning opportunity structures have succeeded only partially. Guarantees of state and/or local autonomy in public schooling, institutional inertia, and path dependence serve as intervening factors between ideologies and interests. They shape the opportunities for change. Yet the values and preferences of policy makers, educators, and parents are often at odds, resulting in conflicts about future developments.

Individual educational trajectories result from school-specific opportunity structures and decision making. Teachers' values and beliefs, training, personal and practical experiences with diverse student bodies and SEN, and the resources and support made available to them influence whether and how they will react to students' diverse range of abilities. The continual challenge is to weigh the supposed benefits of additional resources against the supposed costs of low status, lower expectations, and stigmatization. Teachers' normative expectations differ according to the category into which they sort students, who respond accordingly (Mehan et al. 1986). This reaction is particularly important because special education, despite its good intentions, often reduces learning opportunities instead of increasing them (Tomlinson 1982), as SEN classification becomes a self-fulfilling or selfsustaining prophecy. As long as resources for special education services are bound to stigmatizing labels that provide bureaucratic accountability to justify compensatory provision, the "distributive dilemma of disability" (Stone 1984) - inherent in social and educational policies of all kinds-will remain operative.

Despite Germany's new SEN classification system of educational supports instead of individual deficits, the organizational structures have changed only marginally. The change indicates the effect of human and civil rights chal- 
lenges to the legitimacy of segregation since the late 1960s and the continuous pressure by the global disability rights movement and parent advocates for inclusion and equality. Yet solely primary schools have substantially reduced segregation, due in large measure to their inclusive design since the Reichsgrundschulgesetz of 1920. The educational system's early selectivity continues to operate, and despite limited longitudinal data, studies show that the achievement gap between special school students, when compared with Hauptschule students with similar original performance levels, increases steadily over time, limiting returns to general education (Wocken 2000).

The institutionalization of a new classification system highlighted (1) intractable difficulties of defining disability and SEN, (2) considerable Länder and local variability beyond any biodemographically explainable variance, and (3) the desire of Länder culture ministries to appear as if they were "prointegration" when few have approved broad-based integration even after successful inclusive pilot projects (Cloerkes 2003, 17-22). In a textbook case of loose coupling, school systems have met exogenous demands without changing organizational structures - except for a few marginal additions to existing arrangements. Ideologies of equality and integration, extended to students with SEN, challenge ministry bureaucrats, individual teachers, and other school gatekeepers, yet not enough for them to abandon the competing ideologies of homogeneity and status-appropriate education. Despite international pressure to support integration and inclusive education, Germany's Länder continue to support the interests of those who operate the special school system, viewed by many as the most "appropriate" school type for students with SEN. Policy makers, teachers, and other gatekeepers have changed categories and labels-easily done-while reacting to local or regional demands for more integration in idiosyncratic ways.

In the United States, the ideals of integration and equality facilitated the victory of the special class over the special school early in the twentieth century. Since the 1960s, despite the broad diffusion of minority/sociopolitical paradigms of disability, medical model categories in special education have been maintained, and new ones have been added (e.g., autism). In this self-reinforcing process, such new specializations and categories are professionally legitimated and used to justify the ever-increasing resources required for an expanding population. Integration is the raison d'être of American public schooling, despite the reality of residentially based socioeconomic, racial, or ethnic segregation. Options for support or transfer to special classes favor individualized classification, then separation along a continuum of general and special class time distributions. Importantly, group diversity is also reflected in special education programs. This American strategy of accepting heterogeneity is antithetical to Germany's process of homogenization, elaborate differentiation, and allocation to segregated school types.

More so than the American, Germany's educational systems can resist 
change through the legitimation that results from the congruence between societal and educational idealization of homogeneity within status groups. Teachers know well that referral for diagnosis nearly always leads to classification. Until 1994, it implied immediate allocation to one of the low-status "special" school types, with a correspondingly high classification threshold. This has led to grade retention as the preferred solution. Options for support or transfer to special schools favor retention, then segregation, an option of last resort.

Whereas German schools rely on overall grades and teacher referrals, schools in the United States frequently use psychometric testing as a screening device for special education and retention while maintaining subject-based flexibility in placement. While tests can also be used to "declassify" students, this practice is not commonplace. Nevertheless, the continuum of special education settings contributes to the permeability of tracks within comprehensive schools and a low classification threshold. Unlimited as long as resources are available, gatekeepers view special education as a viable alternative for a large group of students having difficulties or those with challenging behaviors, and parents do not resist but actually demand the additional services it offers. In both societies, however, disadvantaged groups are overrepresented in special education, as general education teachers' difficulties in teaching these students lead them to transfer these students out of their classes using legitimated organizational responses to learning or behavioral issuesmainly retention and special education-affecting an ever larger population.

\section{Conclusion}

This comparative institutional analysis has shown that the development of special education systems reflects a complex of cultural and structural factors operating at multiple levels. While this cross-national comparison has identified an array of similarities and differences in American and German educational systems, questions remain as to the relative importance of each factor, especially at state/Land and local levels, for the past and future institutionalization of special and inclusive education.

Differentiated school structures, bureaucratic divisions, and professional interests resist the reform and restructuring of the existing segregating (German) or separating (U.S.) special education systems and rely on the legitimated institutional logic of each national education system. Each system reflects fundamental societal values and educational ideologies of earlier eras in which special education was institutionalized, as they frame the interests that have successfully fought for special education's diffusion and differentiation. Over the twentieth century, special education expanded and was embedded into existing educational institutions in a subsidiary relationshipwhether in the same school system or the same school building.

While some schools, districts, and even Länder/states have changed spe- 
cial education's organizational structures considerably over the past few decades, others have been unable or unwilling to overcome the barriers delineated above. Regional variation shows that path departure toward inclusive education is possible, albeit at a gradual rate of change-measured in hundreds or thousands of students (i.e., single-digit, not double-digit percentages). Changes in finance (from flat grants to enrollment based) could reduce the need for classification by providing additional resources for services directly to schools to allocate when and where necessary. Alternative models provide ways to modify bureaucratic procedures that foster collaboration, problem solving, and flexibility in meeting individual needs instead of focusing attention mainly on diagnosis and procedural compliance (Skrtic 1991). Shifting professional interests from the maintenance of special schools and classrooms by modifying state/Länder policies that have built-in incentives to classify and separate or segregate students is a necessary but not sufficient condition to facilitate inclusive education.

Nevertheless, the cross-national divergence in such indicators as education population size and composition, learning opportunity structures, and educational attainments cannot be explained by reference to individuals' disabilities and disadvantages but, rather, can be understood by analyzing the long-term institutional developments in the educational systems that brought forth highly differentiated special education organizations to serve a plethora of interests, guided by powerful ideas about abnormality, disability, and SEN. Along with rising rates of inclusive schooling, special education's self-reinforcing expansion continues-enabled primarily by general educators' authorized continual supply of students-as many parents value the additional resources and specialized, professional services of special education more than they fear the potential stigma of such participation. A major challenge to special and inclusive education alike is that there is no national consensus in public and professional discourse or in educational and social policies, thus requiring interpretation in local contexts to draw the boundaries that guide individual actors to make these often difficult choices. In the United States and Germany, the persistence of institutionalized special education systems that segregate and separate poses a considerable challenge to the restructuring of schools to become more inclusive-where that global vision is accepted.

\section{References}

Andrews, J. E., D. W. Carnine, M. J. Coutinho, E. B. Edgar, S. R. Fornes, L. S. Fuchs, D. Jordan, J. M. Kauffman, J. M. Patton, J. Paul, J. Rosell, R. Rueda, E. Schiller, T. Skrtic, and J. Wong. 2000. "Perspective: Bridging the Special Education Divide." Remedial and Special Education 21 (5): 258-60.

Archer, M. S. 1984. Social Origins of Educational Systems. London: Sage.

Baker, B. 2002. "The Hunt for Disability." Teachers College Record 104:663-703. 
POWELL

Baker, D., and G. K. LeTendre. 2005. National Differences, Global Similarities: World Culture and the Future of Schooling. Stanford, CA: Stanford University Press.

Bellah, R. N., R. Madsen, W. M. Sullivan, A. Swidler, and S. M. Tipton. 1985. Habits of the Heart. Berkeley: University of California Press.

Below, S. von. 2002. Bildungssysteme und soziale Ungleichheit [Educational systems and social inequality]. Opladen: Leske \& Budrich.

Booth, T., and M. Ainscow. 2002. The Index for Inclusion. Bristol: Centre for Studies on Inclusive Education.

Carrier, J. G. 1986. "Sociology and Special Education: Differentiation and Allocation in Mass Education." American Journal of Education 94 (3): 281-312.

Cloerkes. G. 2003. "Zahlen zum Staunen: Die deutsche Schulstatistik" [Extraordinary figures: German school statistics]. In Wie man behindert wird [How one becomes disabled], ed. G. Cloerkes, 11-23. Heidelberg: Winter.

Daly, M. C. 1997. "Who Is Protected by the ADA? Evidence from the German Experience." Annals of the AAPSS 549 (January): 101-16.

Degener, T. 2001. "Gesunder juristischer Menschenverstand?” ["Healthy” legal reasoning?]. In Normalität, Behinderung und Geschlecht [Normality, disability and gender], ed. U. Schildmann, 43-61. Opladen: Leske \& Budrich.

DiMaggio, P. J., and W. W. Powell. 1983. "The Iron Cage Revisited: Institutional Isomorphism and Collective Rationality in Organizational Fields." American Sociological Review 48 (2): 147-60.

DiMaggio, P. J., and W. W. Powell. 1991. "Introduction.” In The New Institutionalism in Organizational Analysis, ed. W. W. Powell and P. J. DiMaggio, 1-38. Chicago: University of Chicago Press.

European Union. 2008. Resolution on the Situation of Persons with Disabilities in the European Union. Report 6941/08. Brussels: European Union.

Friedland, R., and R. R. Alford. 1991. "Bringing Society Back In." In The New Institutionalism in Organizational Analysis, ed. W. W. Powell and P. J. DiMaggio, 232-63. Chicago: University of Chicago Press.

Fuchs, D. 2000. "Die demokratische Gemeinschaft in den USA und in Deutschland" [Democractic community in the U.S. and Germany]. In Die Vermessung kultureller Unterschiede: USA und Deutschland im Vergleich [The measure of cultural differences: Comparing the U.S. and Germany], ed. J. Gerhards, 33-72. Wiesbaden: Westdeutscher.

Garnier, M. A. 1980. "Education as Loosely Coupled Systems in West Germany and the United States." In Comparative Public Policy and Citizen Participation, ed. C. R. Foster, 87-98. New York: Pergamon.

Hamilton, S. F., and K. Hurrelmann. 1994. "The School-to-Career Transition in Germany and the United States." Teachers College Record 96:329-44.

Heidenheimer, A. 1984. "Education and Social Security Entitlements in Europe and America." In The Development of Welfare States in Europe and America, ed. P. Flora and A. Heidenheimer, 269-304. New Brunswick, NJ: Transaction.

Hofsäss, T. R. 1993. Die Überweisung von Schülern auf die Hilfsschule und die Schule für Lernbehinderte [The transfer of pupils to support schools and schools for the learning disabled]. Berlin: Marhold.

Jepperson, R. 1991. "Institutions, Institutional Effects, and Institutionalism.” In The 
New Institutionalism in Organizational Analysis, ed. W. W. Powell and P. J. DiMaggio, 143-63. Chicago: University of Chicago Press.

Kavale, K. A., and S. R. Forness. 2002. "History, Rhetoric, and Reality: Analysis of the Inclusion Debate." Remedial and Special Education 21 (5): 279-96.

KMK (Kultusministerkonferenz). (2008 and prior years). Sonderpädagogische Förderung in Schulen 1997 bis 2006 [Special education support in schools 1997 to 2006]. Bonn: KMK.

Krappmann, L., A. Leschinsky, and J. J. W. Powell. 2003. "Kinder, die besonderer pädagogischer Förderung bedürfen" [Children with special educational needs]. In Das Bildungswesen in der Bundesrepublik Deutschland [The educational system of the federal republic of Germany], ed. K. S. Cortina, J. Baumert, A. Leschinsky, K. U. Mayer, and L. Trommer, 755-86. Reinbek: Rowohlt.

Lenhardt, G. 2005. Hochschulen in Deutschland und in den USA [Universities in Germany and the United States]. Wiesbaden: Verlag für Sozialwissenschaften.

Leschinsky, A., and K. U. Mayer. 1999. "Comprehensive Schools and Inequality of Opportunity in the Federal Republic of Germany." In The Comprehensive School Experiment Revisited, ed. A. Leschinsky and K. U. Mayer, 13-39. New York: Lang.

Lucas, S. 1999. Tracking Inequality. New York: Teachers College Press.

Mayer, K. U., and W. Müller. 1986. "The State and the Structure of the Life Course." In Human Development and the Life Course, ed. A. Sørensen, F. Weinert, and L. Sherrod, 217-46. Hillsdale, NJ: Erlbaum.

Mehan, H., A. Hartwick, and J. L. Miehls. 1986. Handicapping the Handicapped. Stanford, CA: Stanford University Press.

Meijer, C. J. W., S. J. Pijl, and S. Hegarty. 1994. New Perspectives in Special Education. London: Routledge.

Melnick, R. S. 1995. "Separation of Powers and the Strategy of Rights: The Expansion of Special Education.” In The New Politics of Public Policy, ed. M. K. Landy and M. A. Levin, 23-46. Baltimore: Johns Hopkins University Press.

Meyer, J. W. 1992. "Innovation and Knowledge Use in American Education.” In Organizational Environments, ed. J. W. Meyer and W. R. Scott, 233-60. Newbury Park, CA: Sage.

Meyer, J. W., F. O. Ramirez, and Y. N. Soysal. 1992. "World Expansion of Mass Education, 1870-1980." Sociology of Education 65 (2): 128-49.

Meyer, J. W., and B. Rowan. (1977) 1992. "The Structure of Educational Institutions.” In Organizational Environments, ed. J. W. Meyer and W. R. Scott, 71-97. Newbury Park, CA: Sage.

Münch, R. 2000. "Politische Kultur, Demokratie und politische Regulierung: Deutschland und USA im Vergleich.” In Die Vermessung kultureller Unterschiede: USA und Deutschland im Vergleich [The measure of cultural differences: Comparing the U.S. and Germany], ed. J. Gerhards, 189-207. Wiesbaden: Westdeutscher.

Muñoz, V. 2007. "The Right to Education of Persons with Disabilities." Report of the Special Rapporteur. United Nations General Assembly, A/HRC/4/29 (February 19, 2007), New York.

(NCES) National Center for Education Statistics. 1996. 120 Years of Historical Statistics. Washington, DC: NCES.

(NCES) National Center for Education Statistics. 2006. Digest of Education Statistics, 2005. Washington, DC: NCES. 
POWELL

Neal, D., and D. L. Kirp. 1986. "The Allure of Legalization Reconsidered: The Case of Special Education.” In School Days, Rule Days, ed. D. L. Kirp and D. N. Jensen, 343-65. Philadelphia: Falmer.

OECD (Organization for Economic Cooperation and Development). 2004. Equity in Education: Students with Disabilities, Learning Difficulties and Disadvantages. Paris: OECD.

Parrish, T. 2001. Special Education in an Era of School Reform: Special Education Finance. Palo Alto, CA: AIR.

Peters, S. J. 2004. Inclusive Education: Achieving Education for All by Including Those with Disabilities and Special Educational Needs. Washington, DC: World Bank.

Powell, J. J. W. 2003a. "Constructing Disability and Social Inequality Early in the Life Course." Disability Studies Quarterly 23 (2): 57-75.

Powell, J. J. W. 2003b. "Hochbegabt, behindert oder normal? Klassifikationssysteme des sonderpädagogischen Förderbedarfs in Deutschland und den Vereinigten Staaten" [Gifted, disabled, or normal? Classification systems of special educational needs in Germany and the United States]. In Wie man behindert wird, ed. G. Cloerkes, 103-40. Heidelberg: Winter.

Powell, J. J. W. 2006. "Special Education and the Risk of Becoming Less Educated." European Societies 8 (4): 577-99.

Preuss-Lausitz, U. 2001. "Gemeinsamer Unterricht Behinderter und Nichtbehinderter" [Joint instruction of disabled and nondisabled pupils].Zeitschrift für Erziehungswissenschaft 4 (2): 209-24.

Preuss-Lausitz. 2002. "Untersuchungen zur Finanzierung sonderpädagogischer Förderung in integrativen and separaten Schulen" [Studies of special education finance in integrated and segregated schools]. In Integrationspädagogik [Inclusive education], ed. H. Eberwein and S. Knauer, 514-24. Weinheim: Beltz.

Ramirez, F., and J. Boli. 1987. "The Political Construction of Mass Schooling." Sociology of Education 60 (1): 2-17.

Ramirez, F., and J. Boli-Bennett. 1982. "Global Patterns of Educational Institutionalization." In Comparative Education, ed. P. Altbach, R. Arnove, and G. Kelly, 15-36. New York: Macmillan.

Richardson, J. G. 1999. Common, Delinquent, and Special: The Institutional Shape of Special Education. New York: Falmer.

Rubinson, R. 1986. "Class Formation, Politics, and Institutions: Schooling in the United States.” American Journal of Sociology 92 (3): 519-48.

Roller, E. 2000. "Marktwirtschaftliche und wohlfahrtsstaatliche Gerechtigkeitsprinzipien in Deutschland und den USA" [Market and welfare state principles of justice in Germany and U.S.]. In Die Vermessung kultureller Unterschiede: USA und Deutschland im Vergleich [The measure of cultural differences: Comparing the U.S. and Germany], ed. J. Gerhards, 89-110. Wiesbaden: Westdeutscher.

Savelsberg, J. J. 1994. "Knowledge, Domination, and Criminal Punishment." American Journal of Sociology 99 (4): 911-43.

Scott, W. R. 1995. Institutions and Organizations. Thousand Oaks, CA: Sage.

Skrtic, T. M. 1991. "The Special Education Paradox: Equity as the Way to Excellence." Harvard Educational Review 61 (2): 148-206.

Solga, H. 2002. "Stigmatization by Negative Selection." European Sociological Review 18 (2): 159-78. 
Stone, D. 1984. The Disabled State. Philadelphia: Temple University Press.

Tomlinson, S. 1982. A Sociology of Special Education. London: Routledge.

Turner, R. 1960. "Sponsored and Contest Mobility and the School System." American Sociological Review 25 (6): 855-67.

Tyack, D., and L. Cuban. 1995. Tinkering toward Utopia: A Century of Public School Reform. Cambridge, MA: Harvard University Press.

U.S. Dept. Ed. (U.S. Department of Education). 2007 and prior years. Annual Report to Congress on the Implementation of the IDEA. Washington, DC: U.S. Department of Education.

Villa, R., and J. Thousand. 2005. Creating an Inclusive School. Baltimore: Paul Brookes Publishers.

Ware, L., ed. 2004. Ideology and the Politics of (In)Exclusion. New York: Lang.

Wocken, H. 2000. "Leistung, Intelligenz und Soziallage von Schülern mit Lernbehinderungen" [Achievement, intelligence and social position of students with learning disabilities]. Zeitschrift für Heilpädagogik 12:492-503. 


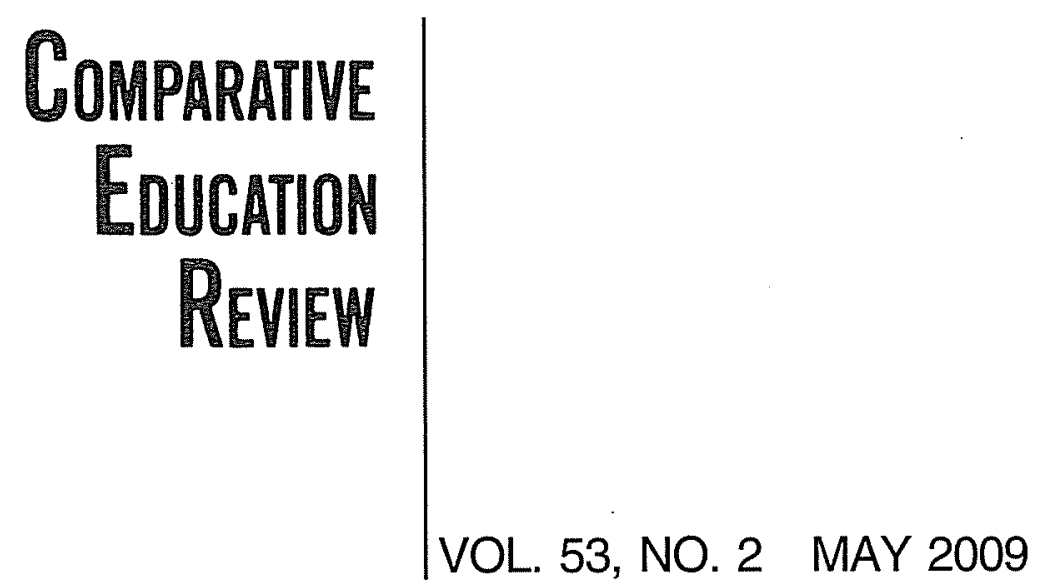

\section{Articles}

JUSTIN J. W. POWELL 161 To Segregate or to Separate? Special Education Expansion and Divergence in the United States and Germany

STEPHEN CARNEY AND 189 Community Schooling in Nepal: A Genealogy of

MIN BAHADUR BISTA Education Reform since 1990

ZVI BEKERMAN, 213 Working toward the De-essentialization of Identity MICHALINOS Categories in Conflict and Postconflict Societies: ZEMBYLAS, AND CLAIRE Israel, Cyprus, and Northern Ireland MCGLYNN

GAD YAIR AND SAMIRA 235 Paralysis at the Top of a Roaring Volcano: Israel and ALAYAN the Schooling of Palestinians in East Jerusalem

\section{Moderated Discussion}

CHRISTOPHER BJORK 259 Preschool in Three Cultures Revisited

\section{Essay Review}

IRVING EPSTEIN 285 Globalization and Youth: Evolving Understandings

\section{Book Reviews}

ALI A. ABDI 295 Reimagining Civic Education: How Diverse Societies Form Democratic Citizens edited by E. Doyle Stevick and Bradley A. U. Levinson

ANGELINE M. BARRETT 297 The Changing Landscape of Education in Africa: Quality, Equality and Democracy edited by David Johnson

MEG P. GARDINIER 299 Citizenship under Fire: Democratic Education in Times of Conflict by Sigal R. Ben-Porath 